\title{
How to Read Karl Barth with Charity: A Critical Reply to George Hunsinger
}

\author{
Matthias Gockel (University of Basel) \\ (accepted for publication, published in Modern Theology 32:2 April 2016, 259-267; \\ DOI: $10.1111 /$ moth.12241)
}

I

For almost a decade now, a dispute over the doctrines of Election and the Trinity has occupied Anglophone interpreters of Karl Barth. After the publication of a volume featuring the main contenders ${ }^{1}$ and an essay written in the spirit of dialogue, ${ }^{2}$ one might have hoped for a respectful mutual acknowledgment without rapprochement. A recent book ${ }^{3}$ puts such hopes on hold.

In order to assess the book, we should remember that Barth hardly qualifies as a traditionalist theologian. From early on, he expresses doubts about prevalent intellectual and cultural assumptions. His biblically oriented dissent from Liberal Theology does not imply the call 'Back to...!' but entails rather a self-critical approach in regard to one's own doctrinal presuppositions. While the magisterial Church Dogmatics $(C D)$ carefully listens to voices from the past, it does not engage in the promulgation of "revealed truths". For Barth, church doctrine by means of human words defines and thus 'limits' the truth of God's own Word, which remains above the dogma 'as the heavens are above the earth' ( $C D \mathrm{I} / 1,266$; further citations are given by volume and page). The 'real results' of dogmatic theology, 'even if they occur in the form of most positive statements, can themselves only be new questions [about the relation] between what the Church seems to proclaim and the Bible seems to / want proclaimed' (I/1, 268-269, rev.). Doctrinal reflection is an 'open inquiry'4 into the relation between proclamation, Scripture, and revelation.

The revisionary character of Barth's theology comes to the fore in his doctrine of election $(C D \mathrm{II} / 2)$. The preface announces that here he 'had to leave the framework of theological tradition to an even greater extent than in the first part of the doctrine of God' in $C D \mathrm{II} / 1$; due to his meditation on the biblical texts he was 'driven irresistibly to

\footnotetext{
${ }^{1}$ Michael Dempsey, editor, Trinity and Election in Contemporary Theology (Grand Rapids, MI/Cambridge, UK: Wm. B. Eerdmans Publishing Company, 2011).

${ }^{2}$ Kevin W. Hector, 'Immutability, Necessity and Triunity: Towards a Resolution of the Trinity and Election Controversy', Scottish Journal of Theology 65, no. 1 (2012): 64-81. It concludes with the wish that, at least, "it may encourage the controversy's participants (and onlookers) to strive to see one another, as far as possible, as being just as rational and, indeed, just as 'Christian' as those with whom they agree" (ibid., 81).

${ }^{3}$ George Hunsinger, Reading Barth with Charity: A Hermeneutical Proposal (Grand Rapids, MI: Baker Academic, 2015), xvi +186 pp (all future references will be given in the text). The author teaches Systematic Theology at Princeton Theological Seminary. I

${ }^{4}$ Christine Helmer, Theology and the End of Doctrine (Louisville, KY: Westminster John Knox Press, 2014), 79.
} 
reconstruction' (II/2, 2, rev.). Barth rejects the traditional idea of a decretum absolutum, or God's inscrutable will of predestination, and instead builds on the decretum concretum, or God's eternal will in the election of Jesus Christ. He also revises the concept of double predestination along the lines of his earlier criticism of the idea of two separate groups of persons. ${ }^{5}$ He now speaks of God's two-fold determination of Himself and of humankind, in which God takes upon Himself the death and condemnation of the sinner, while humankind is destined to bear the splendor of God's glory. God's gracious election (Gnadenwahl) is identical with Jesus Christ, who is not only the elect human, in whom all other human beings are elected, but also the electing God. 'We do not have to ask for any other than for him' (II/2, 115, rev.).

How shall we understand this divine self-determination? Barth's position is not always easy to grasp. Clearly, the gracious election specifies not only God's 'external' dealings with creation but also God's very being. It is an eternal covenant 'that God, in regard to humankind, made with Himself in His pre-temporal eternity' (II/2, 104, rev.). Is it therefore, in some sense, a constitutive or necessary aspect of God's being, and what would this imply for the doctrine of the Trinity, given that Jesus Christ, as the electing God, chooses not alone 'but in company with the electing of the Father and the Holy Spirit' (II/2, 105)?

Barth himself does not address the question. Some interpreters, including yours truly, argue that a number of passages, especially but not exclusively from $C D$ II/2 onwards, ${ }^{6}$ lend support to a positive answer but others do not and that these statements cannot be harmonized. Others, especially George Hunsinger and Paul D. Molnar, argue that the problem does not exist, since Barth consistently maintains the priority of Trinity over Election. Hunsinger has come to label the two views the / 'revisionist' and the 'traditionalist' reading. ${ }^{7}$ Both agree that, for Barth, God's being is a being-in-act and 'inseparable from a

${ }^{5}$ This criticism is already found in Barth's second Commentary on Romans (1922). See Matthias Gockel, Barth and Schleiermacher on the Doctrine of Election: A Systematic-Theological Comparison (Oxford: Oxford University Press, 2007), 109-110. Barth does not hesitate to admit 'a hole in the cloak of my orthodoxy'. See Karl Barth, Unterricht in der christlichen Religion, vol. 2, edited by H. Stoevesandt (Zurich: Theologischer Verlag, 1990), 183; The Göttingen Dogmatics. Instruction in the Christian Religion, translated by G. W. Bromiley (Grand Rapids, MI: Wm. B. Eerdmans Publishing Company, 1991), 453.

${ }^{6} C D \mathrm{II} / 2$ signals not a break but a new turn in Barth's thinking, and even before that Barth sometimes says that God in His triune being already is 'God for us'. See $C D \mathrm{I} / 2,34-35$ : God 'had to become manifest to us. Why? Because already from eternity, already in Himself, before we or the world existed, He was ready and open for us, He was confederated with us in His Word or Son.' Similar statements can be found in $C D$ I/1. See the meticulous analysis by Hans Theodor Goebel, 'Trinitätslehre und Erwählungslehre bei Karl Barth: Eine Problemanzeige', in D. Korsch and H. Ruddies, editors, Wahrheit und Versöhnung: theologische und philosophische Beiträge zur Gotteslehre (Gütersloh: Gütersloher Verlagshaus Gerd Mohn, 1989), 147-66. To my knowledge, this important essay is never discussed by the "traditionalists". Goebel also is the author of the most comprehensive monograph on Barth's doctrine of election. See Hans Theodor Goebel, Vom freien Wählen Gottes und des Menschen. Interpretationsübungen zur "Analogie" nach Karl Barths Lehre von der Erwählung und Bedenken ihrer Folgen für die Kirchliche Dogmatik (Frankfurt am Main: Peter Lang, 1990). /

7 The term "revisionist" is loaded. It gained prominence through David Tracy's seminal book Blessed Rage for Order: The New Pluralism in Theology (New York: Seabury, 1975 / 1996 second edition). Tracy, a Roman-Catholic theologian and priest, used the term to express the need for a 
decision' (9). The dispute concerns the nature of the decision. The "revisionist" side is said to think that God's triune being is 'subsequent to God's relationship to the world', whereas the "traditionalists" insist that it is 'logically and ontologically antecedent' (10). The "principle of charity" implies that one first understand a viewpoint 'in its strongest form' (xii) before criticizing it. If one reads Barth and adheres to this principle, the book suggests, one will discover that the "revisionist" reading fails to "rest its case on a detailed engagement with the actually existing textual Barth' (113).

Chapter 1 takes aim at Bruce McCormack's essay 'Grace and Being: The Role of God's Gracious Election in Karl Barth's Theological Ontology' (2000). Chapter 2 addresses 'an important exchange' (39) between Edwin van Driel and McCormack from 2007. A onepage 'Interlude' then brings forward the main charges against "revisionism" alleging '(1) a rationalistically deduced picture of Barth derived from abstract propositions; (2) a penchant for accusing Barth of self-contradiction without recourse to testing this perception by applying the principle of charity; and (3) a black-and-white mode of thinking [...] as if there were no complexities and no shades of gray' (73).

Chapter 3 turns to Paul T. Nimmo's book Being in Action: The Theological Shape of Barth's Ethical Vision (2007) and his essay on Election and Pneumatology. Chapter 4 claims, surprisingly, that the 'driving interest' of the book has to do with Barth and 'not with revisionism' (115, italics added). Hunsinger reflects on the question 'how can Barth say that before God acts graciously ad extra his antecedent being must include grace in itself?' (117, referring to the claim that grace is not an attribute 'that could be imputed or not imputed' to God: 'No, God Himself is gracious, and grace is itself properly and essentially divine' [II/1, 356 , rev.].). The chapter also considers 'the obedience of the Son of God' (CD IV/1, § 59) and the teleology of God's being 'in Himself' and 'with us', which Hunsinger, taking up concepts from Barth, calls an act of God's 'self-repetition' in 'correspondence' with Himself: from God's Trinitarian history 'in Himself' towards God's self-revelation and history 'with us' (124). Finally, he notes that Barth's theology balances an "Anselmian" dimension concerning God's perfections and a "Hegelian" dimension concerning God's dynamic beingin-act and participation in world-history.

Chapter 5 discusses Paul Dafydd Jones, The Humanity of Christ: Christology in Karl Barth's Church Dogmatics (2008), which is absolved from the above mentioned charges, although Hunsinger alleges an 'opting for terminological imprecision' leading to 'rhetorical extravagance' (139). Jones' position is said to be partially redeemable, if 'the rhetorical excess is trimmed back, and if the ambiguities are resolved in a particular direction' (ibid.). The trimming is undertaken by the distinction between 'eternal constituents' (God's triune being without the election of Jesus Christ), 'essential predications', and contingent 'material determinations' (ibid.), so that the triune God remains the same eternally and essentially, while freely choosing to be affected / by contingent properties, such as suffering. Jesus' history is God's history, but this does not entail that 'God historicizes his eternal being' (156). Still, the concept of incarnation or Menschwerdung implies that God participates and is

comprehensive re-evaluation of Christian truth-claims with the help of Tillich's method of correlation. One could label his approach post-liberal as well as post-neo-orthodox, but these labels need further explanation, which is not our task here. / 
involved in history. It would be more precise to say that God does historicize God's being, without giving up His Godhead.

The Conclusion repeats key points and offers two final thoughts about God's eternal act and the claim that God is 'unconditioned by anything other than Himself' (169).

II

The interpretation of Barth is performed charitably, but occasionally the author overstretches his bow (more on this shortly). Texts by theological opponents are not afforded the same care. Two central essays by McCormack, who also teaches at Princeton Theological Seminary, are ignored. ${ }^{8}$ Both of them assert that Election and God's Tri-unity are equally primordial, in an ontological sense. ${ }^{9}$ The discussion of van Driel's critique and McCormack's response offers neither a single quotation nor a summary of the response. One hundred pages later we find some snippets from a paragraph, in which McCormack rejects the charge of "Hegelianism" (170), but his constructive engagement of Barth goes unnoticed.

Chapter 3 mentions Paul Nimmo's reading of $C D$ IV/1, 182-210. Instead of engaging it in detail, however, the book launches a 25-page paraphrase of Barth's text, without providing the reader any information about Nimmo's own interpretation of the same text (or other texts). Another section cites from and judges Nimmo's argument:

[I]t is proposed that we think about the Holy Spirit as the 'elected God' along with Jesus Christ. An opinion is then offered: 'While Barth himself does not avail himself of such a statement, it seems likely that he would offer his assent to it' ([Nimmo,] 167). On the contrary, however, nothing could be more unlikely than Barth's assenting to such a statement. The main reason is that it has no exegetical basis in the New Testament. Nor does it make any doctrinal sense. (85)

When one reads what Nimmo says, a very different picture emerges. The cited page explains that the Holy Spirit, as the Spirit of the Father and of the Son, 'has no need of any special election'. On this claim Nimmo then comments (see above): 'While Barth himself does not avail himself of such a statement, it seems likely that he would offer his assent to it'. The book thus misrepresents the criticized position - surprisingly, since the claim that the Holy Spirit needs no special election might be agreeable even for Hunsinger. I

In a discussion of his new approach, Barth reminds us that the fact that Jesus Christ is the Son of God 'does not rest on election' (II/2, 107, italics added). The book quotes the reminder several times, paraphrasing that 'Jesus Christ's identity as God's Son' (xi.13) does not rest on election. In one sense, this is correct, yet Barth also says in the same passage: Jesus Christ's humanity, precisely as the Son of God, does rest on election. Barth explains that Thomas Aquinas highlights two aspects about the person of Christ and Election: the

8 'Election and the Trinity: Theses in response to George Hunsinger', Scottish Journal of Theology 63 (2010): 203-224, and 'The Doctrine of the Trinity after Barth: An Attempt to Reconstruct Barth's Doctrine in the Light of his Later Christology', in Myk Habets and Phillip Tolliday, editors, Trinitarian Theology after Barth, Princeton Theological Monograph Series 148 (Eugene, OR: Pickwick Publications, 2011), 87-118.

${ }^{9}$ In $C D \mathrm{II} / 1,356-57$, Barth says there is 'no higher divine being' besides God's gracious being and that God is gracious 'even when He is for us the unknown and hidden God.' This passage alone, although it does not yet mention God's gracious election, should preclude the assumption of an ontological distinction between Trinity and Election in Barth's thinking. I 
eternal deity of Christ, which needs no election, and the elected humanity; election thus implies a passive relation of Jesus Christ to God and is limited to His human "nature". Yet Thomas does not recognize the active involvement of Jesus Christ or 'the being of Jesus in the beginning with God' (II/2, 107, rev.): the Son of God as such is the human being sent into the world as the 'bearer of the divine name of the Father' (ibid.). The election of Jesus Christ is not limited to His human "nature". His 'identity' as God's Son thus rests on election - to the extent that the Son of God, and no one else, chose to live the life of the human being Jesus of Nazareth. ${ }^{10}$ Hunsinger's interpretation underplays Barth's hand, as it were.

In the next section, we will clarify an ambiguity that could spread confusion among novices to the debate and then address some interpretive issues.

\section{III}

1. The book's presentation of the opposed position is ambiguous. The first paragraph portrays "revisionism" as contending that for Barth God's gracious election is the ground of God's triune identity. Later, we hear: 'if only the revisionists [...] cease[d] ascribing their views to Barth, they would have nothing to fear from his more careful readers' (115). In contrast, the first chapter mentions that the "revisionists" are well aware that Barth "never reversed the order of the Trinity and election' (14). Here, they do not contend that for Barth the gracious election comes first.

What they do, in fact, is to reflect on the implications of Barth's doctrine of election for his doctrine of the Trinity and other doctrines. Moreover, they have acknowledged more than once that some texts in the $C D$ stand in tension with their own views. This acknowledgment entails that an emphasis on those passages where Barth might oppose the "revisionists" does not necessarily undermine the latter's own doctrinal claims - after all, it is possible that even the so-called "traditionalist" Barth erred. In this regard, the book's argument leads nowhere.

2. The first interpretive issue relates to the idea that Jesus Christ is not only the object but also the subject of election. The book analyzes Barth's idea of the 'one indivisible but internally differentiated event' (65-66) of Election. Barth says (a) the Father elects the Son, while (b) the Son, in consent to this choice, elects himself and (c) 'in electing himself [...] elects the man Jesus into indissoluble unity with himself' (65). The second aspect, the selfelection of the Son, is His election for the covenant: 'in and with his election of the man Jesus, the eternal Son elects himself' (61; cf. II/2, 105). Yet, the self-election of the Son is also said 'to precede (logically and ontologically) his election of Jesus' (62, referring to II/2, 107). How can it be so, when the election of Jesus of / Nazareth occurs 'in and with the selfelection of the eternal Son' (62, italics added)? Hunsinger, claiming to follow Barth, wants to have it both ways: the election of the Son of God precedes the election of Jesus and is identical with it.

\footnotetext{
${ }^{10}$ Hunsinger himself once said that, for Barth, 'the human existence of Jesus is accorded not only epistemological but ontological priority' for every Christian doctrine; eternity is 'ontologically filled and shaped' by the 'particular temporality of Jesus'. George Hunsinger, How to Read Karl Barth: The Shape of His Theology (New York: Oxford University Press, 1991), 16-17. I
} 
3. The verb 'to precede' leads us to the next issue, the relation between God's triune being and the election of Jesus Christ. ${ }^{11}$ Barth mentions an eternal will of God that 'precedes even predestination' and can be known 'only as the act, in which God from eternity and in eternity affirms and confirms Himself' (II/2, 155), that is, presumably, the 'so-called immanent Trinity' $(I / 1,479)$. At the same time, Barth insists that the election of Jesus Christ also is an act in which God eternally confirms Himself and by which God has bound and committed Himself eternally 'to be the God of human beings' (II/2, 177). Barth says: 'There is no such thing as a will of God different from the will of Jesus Christ' (II/2, 115, rev.). Yet, the idea of God's eternal will apart from the gracious election suggests that God's commitment and selfdetermination to be the God of the covenant could be reversed and that there is a will of God different from the will of Jesus Christ.

The book offers the following model: there is indeed one eternal act and will of God (cf. 18), but it has two aspects. ${ }^{12}$ The primary aspect is God's act and will 'in Himself', which is non-contingent, the second aspect is God's act and will 'by grace', which is non-necessary (cf. 29; 46n.4). God's will 'preceding' predestination would concern God's non-contingent or 'eternally necessary' triune being, while God's will in Jesus Christ and the gracious election would concern God's non-necessary (or 'eternally contingent') being as Creator, Reconciler, and Redeemer.

Unfortunately, the construction does not hold. For Barth, election or God's being 'by grace' belongs to God's being 'in Himself' (as the book recognizes!) and transcends the alternative "necessary" or "contingent". Moreover, the term 'contingent' commonly refers to an event that can occur or not occur. In our context, it is used for a property 'whose existence or nonexistence for God is equally possible' (141). In this view, God eternally can be or not be the electing God, which does not correspond to Barth's key conviction that the basis of all 'Christian truth'is the belief that 'from and to all eternity God is the electing God. [...] There is no height or depth in which God still or yet again would be [wäre] God in any other way' (II/2, 77, italics added). Barth's use of the irrealis puts into doubt the idea that God can be or not be, let alone wills to be or not to be, the electing God. 'Grace is not merely a gift of God that God could give or not give, or an attribute that could be imputed or not imputed to Him. No, [...] grace is itself properly and essentially divine' (II/1, 356, rev., italics added).

4. In a few instances, the book ignores the plain sense of Barth's text. For example, Barth says that the object of election is 'the Son of God in His determination as the Son of Man, the pre-existing God-Man, Jesus Christ, who as such is the eternal basis of the whole divine election' (II/2, 110, rev., italics added). The book modifies the meaning by an insertion that makes it appear as if only 'the triune God in and through the Son' (56) were the eternal basis of election. This is not what Barth says. He rather implies / that God's triune being and God's

\footnotetext{
${ }^{11}$ See Gockel, Barth and Schleiermacher on the Doctrine of Election, 178-179.

${ }^{12}$ Here, Hunsinger differs from his fellow "traditionalist" Molnar, who speaks of " $t w o$ distinct acts'. Paul D. Molnar, 'Can the Electing God be God without us? Some Implications of Bruce McCormack's Understanding of Barth's Doctrine of Election for the Doctrine of the Trinity', Neue Zeitschrift für Systematische Theologie und Religionsphilosophie 49 (2007): 199-222, 202 (italics added). Molnar regularly accuses "revisionism" of 'collapsing' or 'conflating' the gracious election and God's tri-unity 'into a single act' (ibid, 208n.19, see also 202, 204). I
} 
gracious election are both ontologically primordial. Hence, both are called a 'primal decision' (cf. II/2, 9.50.76.103). Furthermore, in a passage that supports the "revisionist" reading, Barth equates the 'eternal predestination', which he identifies with the gracious election (cf. II/2, 145), with God's being as the living and loving God in Himself, that is, the 'inner relations' of Father, Son, and Spirit, so that predestination is the 'origin' of God's manifestation ad extra (II/2, 175). The book does not recognize the equation (cf. 67).

Furthermore, Barth insists that the gracious election is not 'an absolutely free choice' but an act of God's free love. Election is 'the decision by the divine will, which was executed in Jesus Christ and thus pointed to the sending of the Son of God' (II/2, 25, rev.). Barth here criticizes the use of the word 'choice' (Wahl) - not 'election' (Erwählung) - apart from its concrete determination. The criticism is directed against the 'absolutizing' of God's choice and freedom throughout the history of the doctrine, which led to distortions. The book, however, claims that Barth "warns explicitly against "absolutizing" of God's pre-temporal decision of election' (55). Nothing in Barth's text supports this claim. The misunderstanding may be due to the translation, but the point is clear: 'What happens in this choice is under all circumstances this that God is for us' (II/2, 25, rev.). Barth warns against conceptions of Election that obscure this good news. The same is true for his appropriation of the concept of the divine decrees as opera ad extra interna, besides the opera ad intra and the opera ad extra, as an antidote to the view that God is granted 'everything in the way of aseity, simplicity, immutability, infinity, etc. but not the character of a living God [...] in concrete decision' (II/2, 79, rev.).

5. The book refers to passages in $C D$ III/1 which distinguish between God's being in Himself and God's being in relation with the world (see 17-20) or between God's 'absolute being' and 'contingent will' (III/1, 14). To apply these distinctions to the distinction between Trinity and Election (cf. 168), in order to prove that, for Barth, Election is grounded in the Trinity, overlooks the fact that Election belongs to God's being in Himself. ${ }^{13}$ It is not, like creation, a 'unique and contingent positing (Setzung) of heaven and earth by the will and act of God' (III/1, 14) but, like the Trinity, it is the foundation and precondition of creation and of the relation between God and God's creatures, that is, an integral part of God's 'eternal will and decree' (III/1, 14, rev.) and the 'eternal divine essence' (II/2, 50, rev.). As such, it is an expression of 'the necessity of God's free goodness'. ${ }^{14}$

IV

While George Hunsinger's book invited me to re-read Barth closely, it did not convince me that he has read Barth (especially in the German original) or other interpreters of Barth closely enough. On the whole, "his" Barth often appears to be a theologian of the fourth rather than the twentieth century. The book includes appeals to 'the whole ecumenical

${ }^{13}$ Occasionally, Barth himself seems to forget his own insight, for example, in the passage $C D$ IV/2, 345-346, where Election is simply an opus ad extra, in distinction from God's triune being as opus ad intra, while the identity of Election with Jesus Christ is overlooked.

${ }^{14}$ This phrase is used by Barth in his conversation with the "Barth Working-Group" (a group of eight German and Swiss students at the time) on June 7, 1966. Cf. Karl Barth, Gespräche 1964-1968, ed. Eberhard Busch (Zurich: Theologischer Verlag, 1996), 267. I 
tradition' (7) or 'standard Nicene theology' (113), as if these / concepts were selfexplanatory. The dynamic quality of Barth's theology is hardly noticeable. We encounter 'revolutionary theology without the revolution. ${ }^{15}$ The last phrase is a quote from Hunsinger's first and widely acclaimed monograph on Barth, which included statements that today would support the 'revisionist' reading.

One formulation epitomizes the "traditionalist" view of Barth: the charge that he assumes an 'ontological divide between the Creator and the creature' (162, see also 19n.21, 125). This, however, is not Barth's terminology. While he certainly assumes a distinction between God and God's creation, the phrase 'ontological divide' suggests a separation and a thinking remoto Christo, in abstraction from God's 'original covenant' (IV/1, 44) with humankind. In contrast, when the $C D$ uses the adjective 'ontological', it speaks of the fellowship and not the distinction, let alone the divide, between God and human beings. To give only two examples: Barth's ethics of Creation explains that 'the ontological bond that binds every human being to God is the honor that God displays to him or her [...] in the fact that $\mathrm{He}$ is and remains their Creator and Lord, so that the human being, for his or her part, however well or badly, was and is and will be God's creature' (III/4, 652, rev.). ${ }^{16}$ Moreover, the introductory paragraph of the doctrine of reconciliation speaks of God's grace as 'the ontological substance' of the 'original relationship' between God and humankind (IV/1, 44).

In order to support his claim, Hunsinger offers two quotes, but neither of them uses the adjective 'ontological'. The first describes God present in Jesus of Nazareth as 'the One who is qualitatively different [...] in relation to all other human beings and the whole cosmos' (IV/1, 176, rev.). The second passage, in the German original, speaks of 'an "infinitely qualitative distinction" (IV/2, 61, rev.). The use of scare quotes, which are omitted in the English translation, makes it clear that Barth cites from his own preface to the second edition of his Commentary on Romans, where the 'infinite qualitative distinction' famously appears. The context of this passage, too, highlights the relation, not the separation, between God and humankind. ${ }^{17}$ To say / that human beings are created is to say that they are

15 Hunsinger, How to Read Karl Barth, 11. Hunsinger's comment on T. F. Torrance's interpretation neatly describes his own reading of Barth, twenty-five years later: 'The energy, dynamism, and sense of collision which enter Barth's theology by way of the actualistic and particularistic motifs never quite come through [...] Instead of actualism and particularism enlivening the objectivism, the objectivism is allowed to mute and soften the actualism and particularism' (ibid.).

${ }^{16}$ Similarly, Barth's anthropology says: 'The ontological determination of humankind is grounded in the fact that Jesus is one human being among all other human beings' ( $C D \mathrm{III} / 2,132$, rev.).

${ }^{17}$ Karl Barth, Der Römerbrief. Zweite Fassung 1922, edited by K. Tolstaja and C. van der Kooi (Zurich: Theologischer Verlag, 2010), 17. In general, the phrase needs to be treated with caution, as a passage from $C D$ IV/2 shows. Barth begins: 'However we may define divine and human essence, unless we come too close either to the one or the other we can only define them (with all the regard for the original God-relatedness of human essence!) in sharp distinction and even antithesis. Hence, the proposition about Jesus Christ as the One who is of divine and human essence dares to unite that which by definition cannot be united.' Barth then adds: Jesus Christ, as the Son of God, stands in 'infinitely qualitatively difference' from the being of creation and non-divine reality, while as the Son of Man he stands in 'infinitely qualitative difference' from the being of the triune God 'as Creator and Lord over all things' (CD IV/2, 61, rev.). Does this proposition do justice to the confession that Jesus is the Son of God (Mark 15:40)? In contrast, $C D$ II/2 emphasizes that God's 'specific act' in the 'primal decision' of the gracious election 'is as such the constitution (Grundgesetz) of His Lordship and sovereign rule as a whole. The doctrine of election is rightly grounded when, in respect of the 
fundamentally bound to their Creator, while sin, and not creation, establishes the 'radical otherness' that separates human beings from God. ${ }^{18}$ The real ontological divide is the opposition between God and sin. The ideas of God as 'Wholly Other' and the 'infinite qualitative difference' between God and humankind should be understood as expressions of this divide rather than as designations of the relation between God and creation.

In the end, Barth finds the center of theology not in human words and doctrines, be it about Election or the Trinity, but in the living person of Jesus Christ. He adds: 'Who and what Jesus Christ is, is something that can only be narrated, not a system which can be looked at and described' (II, 180, rev.). Future readings of Barth should heed this insight by avoiding an overly "systemic" approach that presses Barth's thinking into received doctrinal models without carefully testing the adequacy of these models in the light of God's unique and particular self-revelation in Jesus Christ.

elected human as well as the electing God, it does not deal with a generality and a divine of human abstraction [e.g., a divine and human 'essence'] but with the particularity and the concretion of the true God and the true human, when from that starting-point it goes on to perceive and to understand whatever there is of consequence about God and about humankind in general; from that starting-point alone, and not vice versa!' ( $C D \mathrm{II} / 2,51$, rev.). Only the latter passage / advocates the reflection from the particular to the general, a move that is widely (and correctly) regarded as typical of Barth's thinking.

${ }^{18}$ Ingolf U. Dalferth, Die Wirklichkeit des Möglichen. Hermeneutische Religionsphilosophie (Tübingen: Mohr Siebeck, 2003), 547. 